\title{
Tomasz Jarmużek, Jutrzejsza bitwa morska. Rozumowanie Diodora Kronosa, Wydawnictwo Naukowe UMK, Toruń 2013, ss. 268.
}

DOI: http://dx.doi.org/10.12775/RF.2016.018

Omawiana książka jest systematycznym ujęciem współczesnych rekonstrukcji słynnego rozumowania Diodora Kronosa, zwanego historycznie Argumentem Mistrza. Składa się ona z trzech części i dziewięciu rozdziałów: cztery rozdziały w części pierwszej, trzy w drugiej i dwa w ostatniej. Zawiera obszerną bibliografię obejmującą 304 pozycje. Nie obfituje jednak w bezpośrednie cytaty. Odwołania do cudzych myśli mają raczej charakter komentarzy, porównań i parafraz. Czytelnik ma zatem poczucie, że znakomitą większość tekstu stanowią własne słowa autora.

Nie wiemy dokładnie, jak wyglądał Argument Mistrza, ponieważ rozumowanie to zostało historycznie zapomniane. Wiadomo jednak że, jego twórca, Diodor Kronos, użył trzech przesłanek. Prezentujemy je poniżej w dwóch wariantach, przesłanka druga może być bowiem interpretowana jako mówiąca o wynikaniu logicznym lub o następstwie czasowym:

(D1) Każde zdanie mówiące o przeszłości jest konieczne.

(D2) Żadne zdanie niemożliwe nie wynika ze zdania możliwego.

(D2)' Żadne zdanie możliwe nie staje się zdaniem niemożliwym.

(D3) Istnieje zdanie, które jest możliwe, ale ani nie jest, ani nie będzie prawdziwe $^{1}$.

Dzięki tym przesłankom Diodor wykazał tezę:

(T1) Zdanie jest możliwe wtedy i tylko wtedy gdy jest lub będzie prawdziwe ${ }^{2}$.

Teza ta stała się definicją możliwości Diodora i była naturalnie postrzegana jako deterministyczna.

1 Por. T. Jarmużek, Jutrzejsza bitwa morska. Rozumowanie Diodora Kronosa, Wydawnictwo Naukowe UMK, Toruń 2013, s. 154.

2 Por. ibidem, s. 159. 
Celem książki jest logiczna analiza rekonstrukcji rozumowanie Diodora Kronosa pod kątem struktur czasu, które były w danych rekonstrukcja warunkiem koniecznym poprawności rozumowania. Naturalnym kryterium tego, czy rekonstrukcja ta wspiera determinizm czy nie, stało się rozstrzygnięcie problemu liniowości bądź rozgałęzienia struktury czasu.

Pomimo tego, że język książki jest przystępny, pewne wyzwanie dla czytelnika może stanowić opanowanie aparatu formalnego umożliwiającego odtworzenie Argumentacji Mistrza. Książka została bowiem napisana w tradycji filozofii logicznej, tj. filozofii, która świadomie stosuje do wyrażania i rozwiązywania problemów filozoficznych narzędzia logiki. Tematyka książki obejmuje również zagadnienia semiotyczne i epistemologiczno-ontologiczne, a nawet historię filozofii. Zdecydowaną większość zawartej w niej treści stanowi wprowadzenie - bo temu przede wszystkim służą rozdziały poprzedzające część trzecią. Tę asymetrię można tłumaczyć na kilka sposobów. Po pierwsze, praca może uchodzić za samowystarczalna, tzn. nie wymaga od czytelnika sięgania do innych pozycji w celu pełnego jej zrozumienia. Po drugie, poza głównym celem pracy, tj. odtworzeniem rozumowania zgodnie z pomysłami logików współczesnych, autor realizuje cele poboczne pozostające w związku z głównym tematem książki. Należą do nich m. in.: przedstawienie podstawowych stanowisk filozoficznych w kwestiach prawdy, (in)determinizmu i czasu, prezentacja poglądów Arystotelesa i Diodora Kronosa na temat modalnego zagadnienia możliwości oraz wprowadzenie w zagadnienie logik czasu.

Część pierwszą „Filozoficzne ramy problematyki” otwiera rozdział „Jutrzejsza bitwa morska”. Nie bez powodu nazwa rozdziału pokrywa się częściowo z głównym tytułem książki - treść rozdziału ujawnia przyczyny jego nadania. Problem bitwy morskiej sformułował bowiem Arystoteles, a to nie jego rozumowania ma dotyczyć książka (przynajmniej tak sugeruje podtytuł). Według autora, Diodor może zostać uznany za oponenta Arystotelesa w sporze o logiczną wartość zdań mówiących o przyszłości. Ten drugi uważa, że nie są one ani prawdziwe ani fałszywe, dopóki w odpowiednim czasie nie stanie się to, co one opisują. Pierwszy twierdzi odwrotnie - przysługuje im wartość logiczna jeszcze przed ewentualnym zajściem stanów rzeczy, do których się odnoszą. Po określeniu historycznych źródeł rozważań przedstawione zostają trzy kluczowe dla dalszych rozważań pojęcia. Są to: prawda, czas i determinizm. Stanowią one kolejno główne tematy trzech następnych rozdziałów.

Rozdział drugi dotyczy zagadnienia prawdy i zdań. Autor pokazuje, że wyrażenia nieodpowiadające pod względem syntaktycznym zdaniom w pewnych warunkach mogą pełnić ich funkcję. Innymi słowy: sąd może przysługiwać wyrażeniu, którego gramatyczna postać nie 
odpowiada zdaniu. Ze względu na problematykę książki najbardziej istotnym jest aspekt czasu w kontekście zdań. Autor wprowadza pojęcie zdania czasowo określonego jako takiego, które na tego typu kontekst nie jest wrażliwe. Jest to koncepcja odpowiadająca zdaniom wiecznym Quine'a. Oprócz tego, przedstawiona zostaje strategia usunięcia zwrotów okazjonalnych i ujawnienia presupozycji zdania przy użyciu kwantyfikatorów. Następnie przedstawione zostają koncepcję prawdy. Podstawowy podział, który przywołuje autor wyróżnia koncepcje epistemiczne i nieepistemiczne. Ze względu na temat pracy w rachubę mogą wejść tylko koncepcje nieepistemiczne. Przywołana zostaje koncepcja prawdy Tarskiego. Autor modyfikuje ją dla celu dalszych rozważań, ograniczając dziedzinę zdań, którym przysługuje wartość logiczna do zdań czasowo określonych, oraz traktując matejęzykową nazwę zdania jako wartość funkcji od argumentu zdaniowego. Dodatkowo wprowadzony zostaje weryfikator $\mathrm{w}$ postaci stanu rzeczy. Ten $\mathrm{z}$ kolei rozumiany jest jako element odpowiedniego przekroju temporalnego świata. Przekrój temporalny natomiast ma być totalnym stanem świata, czyli zbiorem wszystkich stanów rzeczy mających miejsce w odpowiednim momencie.

Kolejny rozdział poświęcony jest zagadnieniu determinizmu. Zwraca się w nim uwagę na zasięg determinizmu, który może mieć ograniczenia merytoryczne, przestrzenne lub czasowe. Opisane więc zostają różne typy determinizmu począwszy od determinizmu ontologicznego. Autor przedstawia trzy zasadnicze problemy, w stosunku do których możliwe jest stanowisko deterministyczne: problem porządku świata, problem źródła tego porządku oraz kwestia istnienia innego, szerszego porządku. Następnie omówiony zostaje determinizm fizyczny, który uznaje jedynie problem porządku świata fizycznego za godny rozpatrzenia. Potem autor opisuje konsekwencje determinizmu. Jedną z nich jest determinizm temporalny, czyli pogląd, według którego zdania posiadają wartość logiczną bez względu na czas zdarzeń, które opisują. Wreszcie określa się stosunek determinizmu do rozumowania Diodora Kronosa. Powołując się na determiznim temporalny, autor określa strategię badania tego rozumowania. Do przesądzenia, czy Diodor był determinista, posłużą logiczne struktury czasu rozgałęzione i liniowe, obecne w logikach, w których jego rozumowanie jest w książce formalizowane.

Rozdział czwarty dotyczy czasu. Zwrócono tam uwagę na wieloznaczność tego pojęcia i konieczność ustalenia poszczególnych znaczeń w celu uniknięcia ekwiwokacji. Dalej przedstawione zostały filozoficzne koncepcje czasu, w ramach których wyróżnia się dwa stanowiska: substancjalne i atrybutywne. Według pierwszego czas jest realnym bytem, drugie mówi, że nie przysługuje mu realne istnienie. Prezentuje się również problem strzałki czasu, czyli kierunku jego upływu. Według niektórych myślicieli, np. Mario Bungego przekonanie o upływaniu 
czasu z przeszłości w przyszłość bierze się z niewłaściwego skojarzenia $z$ nieodwracalnymi procesami fizycznymi. W pracy twierdzi się jednak, że problem ten pozostaje bez bezpośredniego wpływu na kluczowe zagadnienie pracy. Przywołany zostaje również problemat McTaggarta, w którym argumentuje się na rzecz nierealności czasu. Sygnalizuje się również, że przy formalnym ujęciu czasu będzie można uniknąć wielu kontrowersji opisanych wcześniej przez zachowanie ogólności rozważań. Da się to osiągnąć przez zastosowanie teorii mnogości i ujęciu czasu jako struktury, czyli zbioru z porządkującą go relacją. Za dziedzinę tej relacji autor przyjmuje momenty, wskazując jednocześnie na różne możliwe interpretacje tego pojęcia.

Część drugą zatytułowaną „Problematyka” rozpoczyna rozdział „Problem”. Mowa w nim o trudnościach w jednoznacznym określeniu poglądów Arystotelesa na zagadnienie modalności. Rozpatrując różne historyczne interpretacje modalności arystotelesowskich, autor pisze o możliwości przypisania Arystotelesowi determinizmu na podstawie wyznawanej przez niego zasady biwalencji. Dalej przywołuje się jednak fragment, w którym starożytny filozof odmawia konieczności zdaniom mówiącym o przyszłości przy jednoczesnym zachowaniu zasady niesprzeczności i wyłączonego środka. Poglądy Arystotelesa podsumowane zostają stwierdzeniem, że w kwestii przeszłości i przyszłości jest on determinista, odnośnie do przyszłości stoi zaś on na stanowisku indeterminizmu. Dalej autor rozważa relacje Arystotelesa z Diodorem Kronosem. Wskazuje jednak, że znajomość obu myślicieli jest historycznie niepewna. To, co ich łączy, to merytoryczny związek prezentowanych przez nich zagadnień. Wreszcie przedstawione zostaje mistrzowskie rozumowanie, na podstawie, którego Diodor miał sformułować definicję możliwości. Samo rozumowanie mistrza sprowadza się do trzech zdań, które stoją ze sobą w sprzeczności. Współcześni Diodorowi myśliciele jednomyślnie przyznawali faktyczne zachodzenie sprzeczności. Różnice pojawiały się $\mathrm{w}$ kwestii tego, które ze zdań należy odrzucić, aby aporie usunąć. Sam twórca rozumowania optował za trzecim ze zdań, mówiącym o istnieniu nigdy nierealizującej się możliwości, tym samym uzasadniając stanowisko deterministyczne. Autor książki modyfikuje przesłanki rozumowania tak, aby modalności odnosiły się do zdań, a nie do stanów rzeczy. Dalej przedstawiony zostaje tzw. problem futura contingentia, czyli zdań przygodnych o przyszłości, i jego podobieństwo do Arystotelesowskiej jutrzejszej bitwy morskiej. Wprowadzona zostaje również idea czasu rozgałęzionego, jako miara determinizmu lub indeterminizmu logiki, która pozwala zrekonstruować Rozumowanie Mistrza.

Kolejny rozdział dotyczy dat. Autor wskazuje w nim różnicę między datami a zwrotami okazjonalnymi, czyli pseudodatami. Stanowi ją chronologiczna stabilność dat i odpowiednio jej brak w przypadku 
pseudodat. Za denotacje dat przyjmuje się przedziały czasowe zwane interwałami. Jak się okazuje, stan rzeczy nie musi występować w każdym punkcie czasowym z określonego interwału, aby uczynić zdanie mówiące o tym interwale prawdziwym. Stan rzeczy będący weryfikatorem danego zdania może składać się z różnych kombinacji innych stanów rzeczy występujących w mniejszych interwałach czasowych.

Rozdział siódmy nosi tytuł „Logika” i stanowi teoretyczną podstawę dalszych rekonstrukcji argumentacji. Po prezentacji Klasycznej Logiki Zdań, następnie omówione zostają różne logiki temporalne. Jako pierwszy typ przedstawiona zostaje logika pozycyjna w jej czasowej interpretacji ${ }^{3}$. Autor opisuje systemy logik chronologicznych Łosia, Priora i Reschera. Następnie omówiona zostaje logika tensalna. Bazuje ona na modalnej logice z semantyką relacyjną. Od modalnej logiki aletycznej odróżnia ją interpretacja operatorów. Po zdefiniowaniu języka, przedstawieniu interpretacji, określeniu wynikania logicznego i tautologii, autor zaznajamia czytelnika z aksjomatykami wybranych systemów logiki tensalnej. Zwraca uwagę, że nie ma formuły, która odpowiadałaby przeciwzwrotność relacji w modelu. Przyjęcie modeli z relacją zwrotną nie odpowiada intuicjom związanym z naturą czasu i zmusza do przyjęcia kłopotliwych tez. Autor wymienia i udowadnia problematyczne tezy, a następnie proponuje, aby rozpatrywać podstruktury ostrego porządku momentów jako bardziej adekwatne względem ogólnego pojęcia czasu.

Ostatnią część rozpoczyna rozdział "Rekonstrukcje z operatorem Ri". Najpierw omówiona zostaje rekonstrukcja F.S. Michaela. Autor zwraca uwagę, że przy próbie odtworzenia rozumowania pomija ona drugą przesłankę Diodora, co nie czyni ją w pełni adekwatnym odtworzeniem Argumentu Mistrza. Jako że propozycja Michaela ma charakter nieformalny, autor proponuje przyjąć logikę $\mathrm{Rn}+\mathrm{w}$ celu jej formalnego ujęcia. Autor pokazuje, że zaprezentowana teoria wymaga struktur czasu bez końca i początku, która może być zarówno ciągła, jak i dyskretna. Co istotne, przy słabszych definicjach konieczności i możliwości okazuje się, że struktura może być rozgałęziona.

Następnie omówiona zostaje rekonstrukcja Reschera. Tym razem wykorzystane zostają wszystkie przesłanki uwzględnione przez Diodora. W dowodzie używa się modalności chronologizowanych. Przyjmuje się, że zmienne zdaniowe przebiegają po zbiorze zdań czasowo określonych. Logikę uzupełnia się o predykat „bycia wcześniej niż”. Dowód przeprowadzony zostaje na dwa sposoby: zgodnie z intencjami Reschera oraz według uwag Hintikki. Następnie przedstawione zostają definicje standardowe oraz wzmocnione definicje modalności. Struktura czasu, jaką narzuca nam dowód, nie może mieć końca, lecz - wbrew

3 Idee te zostały częściowo rozwinięte w monografii: Jarmużek T., Tkaczyk M., Normalne logiki pozycyjne, Wydawnictwo KUL, Lublin 2015. 
pozorom - nie musi być liniowa. Następnie przedstawia się podobny dowód w ramach nieco inaczej określonego języka, który również dopuszcza struktury rozgałęzione.

Rozdział dziewiąty nosi tytuł „Inne rekonstrukcje”. Najpierw przedstawiona zostaje rekonstrukcja Priora. Rozumowanie zostaje przeprowadzone na gruncie logiki Kt wzbogaconej o aletyczne funktory modalne. W tym wypadku, wydaje się, że przyjęcie struktury liniowej czasu jest konieczne. Jednak autor prezentuje zaproponowany przez siebie i Andrzeja Pietruszczaka model ${ }^{4}$, który ma strukturę rozgałęzioną.

Ostatnią opisaną rekonstrukcją jest rekonstrukcja Øhrstrøma. Zdania interpretuje się tam jako funkcje propozycjonalne od argumentów ze zbioru częściowo uporządkowanego. Ponadto, język składa się z klasycznych funktorów Boolowskich, kwantyfikatorów, znaku „"=", operatorów konieczności i możliwości, specjalnie zdefiniowanej implikacji Diodora oraz dodatkowego operatora odpowiadającego sformułowaniu: „,było tak, że p jest prawdziwe”. W tym przypadku również wydaje się, że struktura czasu może być rozgałęziona.

W recenzowanej książce pokazano, że rozumowanie Diodora Kronosa, przy pewnych interpretacjach, nie musi pociagać determinizmu, który skądinąd w historycznej opinii przylgnął do Mistrzowskiego Argumentu. Nie zostało to jednak tak silnie wyeksplikowane przez samego autora, co można uznać za znamienne dla uprawianej w ten sposób filozofii. W książce Jutrzejsza bitwa morska. Rozumowanie Diodora Kronosa nie znajdziemy pochopnie stawianych tez o wysokim stopniu ogólności.

Krzysztof Aleksander Krawczyk

\section{Bibliografia}

Jarmużek T., Pietruszczak A., The Tense Logic for Master Argument in Prior's Reconstruction, Studia Logica, 2 (2009), s. 85-108.

Jarmużek T., Jutrzejsza bitwa morska. Rozumowanie Diodora Kronosa, Wydawnictwo Naukowe UMK, Toruń 2013.

Jarmużek T., Tkaczyk M., Normalne logiki pozycyjne, Wydawnictwo KUL, Lublin 2015.

4 Por. T. Jarmużek, A. Pietruszczak, The Tense Logic for Master Argument in Prior's Reconstruction, "Studia Logica", 2 (2009), s. 85-108. 